\title{
Editorial
}

\section{Vitamin D - the big D-bate}

In this issue of our journal we have invited a number of experts to comment on the recommended levels of intake of vitamin $\mathrm{D}^{(1-9)}$. This invitation is done in order to shed some light on the ongoing debate regarding the increased recommended level of intake of vitamin D from the Institute of Medicine North America ${ }^{(10)}$. Our Associate Editor Oliver Gillie has also written his own editorial in the area ${ }^{(11)}$.

The journal finds this debate of great importance, not only as a part of a sound scientific debate in general but also with regard to the intriguing nature of vitamin $\mathrm{D}$ and the wealth of factors that influence our vitamin D status. Environmental factors, clothing, seasonal factors, skin colour and intake all have an influence on vitamin D status: the delicate balance between them provides a challenging perspective for public health nutritionists. A recent study of children in Iran revealed a substantial proportion $(32.9 \%)$ of children aged 15-23 months with vitamin $D$ at insufficiency levels ${ }^{(12)}$, significantly more among girls. Iran has a system for encouraging supplementation but the level of compliance is uncertain. This is just one example out of many, showing the need for comprehensive work in this area towards a common consensus on needs, intake, formation and uptake of vitamin $\mathrm{D}$, followed up by policy and action.

Clearly, this is a research field which not only intrigues us but also one that encourages debate. We heartily welcome more debate on vitamin $\mathrm{D}$ as a nutritional issue and also as an overall health issue in relation to environment, shading, skin cancer risk and pollution, as well as outdoor play and activities. We look forward to receiving your views and suggestions.

\section{References}

1. Boucher BJ (2011) The 2010 recommendations of the American Institute of Medicine for daily intakes of vitamin D (Letter to the Editor). Public Health Nutr 14, 740.

2. Giovannucci E (2011) Vitamin D, how much is enough and how much is too much? (Letter to the Editor). Public Health Nutr 14, 740-741.

3. Gorham ED \& Garland CF (2011) Vitamin D and the limits of randomized controlled trials. (Letter to the Editor). Public Health Nutr 14, 741-742.

4. Cannell J (2011) Era or error? (Letter to the Editor). Public Health Nutr 14, 743.

5. Norman AW (2011) Vitamin D nutrition is at a crossroads (Letter to the Editor). Public Health Nutr 14, 744-745.

6. Grant WB (2011) The Institute of Medicine did not find the vitamin D-cancer link because it ignored UV-B dose studies (Letter to the Editor). Public Health Nutr 14, 745-746.

7. Schwalfenberg GK \& Whiting SJ (2011) A Canadian response to the 2010 Institute of Medicine vitamin D and calcium guidelines (Letter to the Editor). Public Health Nutr 14, 746-747.

8. Hollis BW \& Wagner CL (2011) The vitamin D requirement during human lactation: the facts and IOM's 'utter' failure (Letter to the Editor). Public Health Nutr 14, 748-749.

9. Heaney RP (2011) Finding the appropriate referent for vitamin D (Letter to the Editor). Public Health Nutr 14, 749-750.

10. Institute of Medicine (2011) Dietary Reference Intakes for Calcium and Vitamin D. Washington, DC: National Academies Press.

11. Gillie O (2011) Blinded by science, pragmatism forgotten (Editorial). Public Health Nutr 14, 566-567.

12. Olang B, Naghavi M, Bastani D et al. (2011) Optimal vitamin $\mathrm{A}$ and suboptimal vitamin $\mathrm{D}$ status are common in Iranian infants. Acta Paediatr 100, 439-444.

\author{
Agneta Yngve \\ Editor-in-Chief \\ Marilyn Tseng \\ Irja Haapala \\ Caroline McNeill \\ Allison Hodge \\ Deputy Editors
}

